\title{
Igbo African Legal and Justice System: A Philosophical Analysis
}

\author{
Bonachristus Umeogu \\ Department of Philosophy, Faculty of Arts, Nnamdi Azikiwe University, Awka, Nigeria \\ Email: ojiakor99@yahoo.com \\ Received February 23 ${ }^{\text {rd }}, 2012$; revised March 20 $0^{\text {th }}, 2012$; accepted April 2 ${ }^{\text {nd }}, 2012$
}

\begin{abstract}
Law is a body of rules whether formal, written, informal or unwritten that is used to maintain relative peace and order in any given society. Before the advent of civilization, the Igbo people had their own legal system which though might look different in form from the western law but have the same purpose of guiding man into the state of 'oughtness'. This research paper mirrors the legal and justice system of the Igbo people.
\end{abstract}

Keywords: Law; Justice; Igbo; Order

\section{Introduction}

No law has been misconceived like that of the Igbo African law despite the fact that Igbo-African law and other customary laws are one of the most significant sources of what we know as the Nigerian legal system. This is primarily because of the fact that it is unwritten. Does the fact that it is unwritten make it unworthy to be called a law? There are instances that the indigenous laws have been rejected by the courts because "they were repugnant to natural justice, equity and good conscience". Examples of such laws can be found in status impling slavery or servitude in Effiong Okon Ata Ekpan v. Henshaw \& Anor; family law in Amachree v. Goodhead; land law in Awo v. Cookey Gam and a host of others. Before my answer, I need to understand what is really meant by the word "law".

Law is a kind of check to curb the human excesses. It clips the wings of man's absolute freedom so as to maintain order and harmony in any given society. Law can be likened to the bumps placed on a well tarred express road to act as a speed breaker so as to check the speed level of drivers and to ensure the safety of others. Without the speed breaker, people will drive without caution at the detriment of other drivers and passers-by. In our society, the law ensures that we are fair and just in our dealings for a healthier tomorrow. At this point, let us look at some definitions by other writers.

Abayomi (2002: p. 85) defines "law as a body of rules, whether formally enacted or customary, which a State or community recognizes as binding on its members or subjects". In the same vein, Obiwulu (2007) went ahead to maintain that whatever is known as law must "command what is good, forbid what is evil, permit what is indifferent and punish what is contrary".

Barrister Obinewu, a legal practitioner during an interactive session with the researcher gave a functional definition of law as

"Rules and regulations that orders the society; regulates the behaviors of the people; regulates their land (that is why they have different land laws); regulates the family lives of its citizenry (as embodied in family laws); the way the men take wives; relates to their partners; and laws that govern their children".

In the three definitions, I was able to deduce the fact that what makes law is what it is able to achieve; how far it succeeds in realizing the set objectives, and the overall effect of its adherence in the society. This means that whether written or unwritten; traditional or western; civilized or uncivilized; law is law. Having said that, my answer to the above question raised earlier if the unwritten nature of Igbo African law makes it unworthy to be called law; is in the negative. You may like to refer to the cases of status implying slavery or servitude in Effiong Okon Ata Ekpan v. Henshaw \& Anor; family law in Amachree v. Goodhead; land law in Awo v. Cookey Gam cited in the introduction. The Igbo people of Nigeria, since time immemorial, have evolved for themselves some mechanisms of checks and balances which regulate interpersonal relations and order society for progressive transformation. These mechanisms of checks and balances form the structure of what is regarded as Igbo law.

The Igbo African law has been misconceived despite the fact that Igbo African law and other customary laws are one of the most significant sources of what we know as the Nigerian legal system. Not minding its role in the composition of the Nigerian legal system, the body of what constitutes Igbo African law remains, for the most part, unwritten. However, the unwritten status of Igbo African law has not vitiated its ability to maintain relative peace and order; adjudicate matters and pronounce sentences where necessary.

This paper undertakes a philosophical analysis of what constitutes Igbo African law. While doing this, it seeks to identify the salient points that make the Igbo African law stand out from other forms of law.

\section{Characteristics of Law}

I strongly believe that at one point or another, there exists a form of confusion as to what is really law. This made Thomas Aquinas to list some signs that will signify what can be called law. Aquinas in Obiwulu (2007) explained that:

- Law must be an ordinance of reason.

Yes, this is not an all comers affair. For law to be called law means that it must be an embodiment of reasons and objectives that are meaningful, relative and achievable. You don't just wake up and sign anything to law. It is normally thought through. One can now understand why the long and rigorous processes in- 
volved before a bill is signed into law. Okafor (1992:54) explained this point when he wrote that

through the legislative processes involved, the Igbo ensure that any pieces of legislation must have a reasonable foundation and be fair, honest, and easily observable by the law abiding.

- It must be for the common good of the people for who it is made. A law should not be made for selfish purpose of the makers or in the interest of certain number of people.

This is exactly the opposite of what is obtainable nowadays but totally unheard of in the Igbo-African society. Owing to the capitalist nature of the modern world, every law is made to favour a group or groups of capitalists somehow. The powers that be always lobby every bill to tilt or add a clause that will be to their advantage. Here, Aquinas is saying that any law that is not for the good of every member of the society despite the class; social status, financial status, is not worthy to be called law.

The traditional Igbo law also had this covered in the words of Okafor (1992: p. 57) that "the Igbo legislative process which is founded on the principle of 'ohacracy' makes it absolutely impossible for any piece of legislation with sectional bias to be enacted into law". Ohacracy means nothing else other than the general assembly and the power it wields over whatever that is considered to be law. According to Okafor, the tediousness and long processes involved in the legislative process is solely to ensure that the law is in the interest of the common good; that the interest of the poorest and less privileged are protected without compromise.

- It must be made by someone who has care for the community for which the law is being made.

At this point, I would have loved to ask Aquinas who really has care for the community. This is because the people that we believe to care never make it to the corridors of power; and those who made it to the position of authority has another and unique form of caring in mind, and that is caring for their pockets alone. If that is the case, do we still accept the laws made by them even when the care is not directed for the greater good? Or is it okay that a form of care is involved? I still insist that the promotion of the common good is one of the most important criteria for assessing the efficiency and goodness of any law and through it; people in the society are able to achieve their private individual goals.

\section{The Nature of Igbo African Legal and Justice System}

Igbo African law may be referred to as the indigenous native laws and customs of the Igbo people of Africa or native laws and customs of various nationalities or national of Africa. Technically, for the purposes of systematization of studies, it is referred to as customary law of the various people, for example in Nigeria; there are customary laws which are as many as the various ethnic groups in Nigeria. This means that we have Igbo customary law, Hausa customary, Yoruba customary law and what have you. Customary laws have been the body or corpus of laws and customs that is indigenous to each ethnic group and evolved from time immemorial. We note that the possession of those native laws and customs is not peculiar to Igbo people. As such, every ethnic group in Nigeria has its own legal system and body of laws.
Within the Igbo native law and custom which is the focus of this paper, there are shades of variations. The north of Igboland, like Nsukka area that have a boundary with Igala kingdom, have laws that are quite different from the Western and Eastern Igbo. To this effect, the Igbos have a saying that "mba na asu na olu na olu” which means that every community has its own way of doing things.

English/Western law is the type of law that the English or British people came with into Nigeria and other English speaking colonies. They came in with their body of law that is called common law of England that evolved over long period of time. They also have statues which the Imperial parliament made. They have a standing law making body called the parliament. Among it also are the proclamations made by the crown who is either a man-king or a woman-queen. This body of law is what is called western law.

The functional definition of law is applicable in the Igbo native setting. They have laws that govern virtually every aspect of their lives ranging from marital life, succession, to even their streams. The communities that have rivers and streams and ponds have ancient maritime laws that govern the waters. For example, Umuchu in Aguata local areas of Anambra State have a stream called Uchu. One of the laws that govern the stream is that you do not wear any form of clothing to swim in the water; one who wishes to fetch water from the stream must ensure that his or her clothes do not touch the stream. Perhaps, the essence of this law may have been the need to avoid contamination of the stream with dirty clothing materials. In some other Igbo communities, their maritime laws have strict prescriptions about days that fishing in the water is permitted. The necessity of this may have been informed by the need to conserve both nature and environment.

\section{Legislative System in Igbo Traditional Society}

Worthy of note is that in the Igbo society, there is no standing legislative body as existing in the modern democracy. An example is the type brought by the westerners. Just like we have the State houses of assembly and the national assembly, it was not so in the Igbo society. Despite not having a law making body, the Igbo people have law making process which is called "iti iwu" (to make laws). Sometimes it is spontaneous or deliberate but is all in a bid to control a mischief or wrong in the society. Every member of the Igbo society is involved in the law making venture by the virtue of their membership in one or more of the various legislative agencies in the Igbo African society include the following:

1) Umunna: the Umunna includes every person born into a family as well as those born into a number of interrelated extended families who share common ancestry. While membership is automatic for the listed category of persons, attendance to meetings and important gatherings is strictly reserved for only male adult members of the Umunna.

There, they discuss, make rules and regulations about how to farm, allot the lands left by their ancestors, farming time, clearing of bush paths and so on. After such sessions, each person goes home and explains to his wife/wives who will in turn passes/pass the message to their children. Through this way, they are able to maintain uniform order in the community.

2) Age grade: The age grade is formed at the village level. It comprises of people who are born within a stated period of time. They are usually not in the Umunna but in the village level. 
They go and make laws relevant to their own circles. Whenever they overstep their boundaries, the elders will call them back to order. It is the age grades of the young people that were used in the acquisition of lands and wars. Writing on age grades, Okafor (1992: 9) opined that

age grade serves as a social indicator which separates the seniors from the juniors, the age grades association is a means of allocating public duties, guarding public morality through the censorship of members behaviour, and providing companionship and mutual insurance of members.

3) Umuada: The 'umuada' are women that are married and automatically regarded as 'nwaada' or 'umuada'. This group of women also makes laws that regulate their members since the Umunna cannot make laws for the 'umuada' and vice versa. Each of these groups does not make laws that will outlaw the other. I think it is always done in the spirit of "biri kam biri" that is, live and let live.

4) Umuokpu: Umuokpu is a collection of umuada from various Umunna. The "okpu" means that they are old; they are more elderly people. In fact, the Umunna dread them so much so that if there is a domestic, matrimonial or land dispute and the Umunna fails, the umuokpu steps in and always addresses the situation.

5) Umudibia: The Dibias in the Igbo setting are medicine men who undertake a number of roles in Igbo society. Some of the function attributed to Igbo dibia including: divination and provision of cures for people's ailments. The dibias are always seen as half human, half spirit (okala madu, okala, mmuo). They make laws that have religious undertones after which they take to the people for acceptance and approval.

6) Ndi nze: They are the titled men and are highly respected in every community. They are one of the legislative agents in the traditional society. They also have the powers to deliberate and agree on laws that will guide their society.

7) Deities/divinity/gods: The deities have known shrines and known priests and priestesses who act as their mouthpieces. As the protector of the community, it has the right to make laws that will not hamper its protective functions.

8) Oha can also be called the general assembly. They are the supreme group or the highest human legislative agency as far as the Igbos is concerned. The Igbo people have always believed that power belongs to the people. They act as a legislative agency because what they sanction is what law becomes. Without the oha vetoing, it becomes a mere decree and not law and therefore not binding on the members since it is considered illegitimate.

9) Mmanwu: The mmanwu is the guild of masquerades. Membership to the guild is open only to male members of a community. The laws made by the masquerades are said to reflect the wishes of the ancestors who even though are no longer physically present, express themselves through the masquerades.

\section{Judiciary System in the Igbo Society}

There is no judicial institution in the sense of professional judges, courts as is obtainable in the British sense. The judicial system in Igbo society is more or less jury based or trial by peers. Also, all the legislative agencies starting from the Umunna to the general assembly also double as the judicial bodies. In other words, there is no clear cut distinction between the different arms of body. For example, the Umunna that make law can also adjudicate on matters. That is why somebody will say "ka m gaa ghanye oji na Umunna”. This is like taking somebody to court. Age grades and umuokpu also perform the same function for its members.

The role of the deity is also prominent in this area. The chief deity in the Igbo African society is the ani pronounced differently as ana, ala etc. Ana is a female deity who functions as the custodian and giver of morality. Any breaking of the morals is called "nso ani" or abomination. These gods are the supreme courts of the various Igbo society. In a case of dispute with lack of evidence, the alleged will swear to his/her innocence or take an oath starting with the Ofo. The powerful shrines known for this are the Ibine Okpabe of Arochukwu, Agbala of Awka, Ogwugwu Akpu Okija to mention but a few.

In discharging justice, the Igbo judicial system looks beyond an offender to all the social groups upon which he is attached. Thus, when a suspected criminal stands before the traditional Igbo seat of judgment; his family, his age grade, his kindred, and his entire community stands with him. As a result of this, it can be said that no one commits a civil or criminal wrong alone. Every civil or criminal offence or wrong has a social dimension. That is why; at the end of the Igbo legal judgment day more than the individual offenders or person are convicted and blamed for the offence or wrong he or she committed. Of course, in the Igbo African courts, the offender does not come alone. He or she comes with his or her people whether they are invited or not. When a guilty judgment is pronounced and atonement is required, all individual that are related to the offender must rally round to make sure that the offender meets the demands of punishment his crime attracts. Whenever an offender fails in making proper atonement for his misbehaviors the consequences, often deadly, does not discriminate between the offender and his relations.

\section{Executive Body}

Like I mentioned earlier, there is a fusion of these arms in the Igbo society. There is nothing like the executive arm of government. Rather, what they have is a collection of elders or council of elders. The Igbos never had any form of monarchy except in the Onitsha, Nri area which they adopted from where they migrated from.

A critical study of these arms of government will show you that they perform the same function as those obtainable with western law or in the English society.

\section{Follow Up Discourse}

The traditional Igbo African law differs substantially from the English law upon which a large chunk of Nigerian law is based. The Nigerian law, as it is practiced by the advocates and professionals of today, deals with the rights and duties of individuals to persons, properties, and all that; but on the contrary, Igbo African law deals with communal rights and duties and actions. There is the tendency to regard Igbo African law as "native law and custom", as "customary law" or "traditional law etc simply because, Igbo-African law is unwritten (Agrapha), not read in the universities and neither does its advocates attend any form of law school. As such, the conclusion was that Igbo African law is not professional law (What makes a professional law?). 
I regard what I have said so far as a popular illusion. It is an illusion, because, there is not the faintest logical reason to substantiate the conclusions. It is popular because many people believe the conclusions to be true. Well, does the fact that many people believe it to be true makes it acceptable? Is it then the fault of Igbo African law that it has been misunderstood? Or is it our fault that, despite our use and practice of the law, our eyes have never penetrated the reality of Igbo-African law? I think it is our fault that we have been led astray by the professionalism of the west. I strongly believe that it is our fault that we have trusted so much on the written "constitution" of the west. I still maintain that we are responsible for the misconception of Igbo African law because of the confusion roused by the western individualistic approach to studies.

However, it is not just our fault but also the fault of our ancestors both remote and proximate but, are we going to lose hope? Not at all, for, in the heart of the land inside Africa, the Igbo African law has become a reality, no more a possibility.

Perhaps, I will go straight to tell you why the reality of the Igbo African law is a "madness" to the west, as well as a hurdle our professional people can never overcome. That point is: law as it is practiced by the advocates and professionals of today deals with the rights and duties of individuals to persons, properties, and all that; but on the contrary, Igbo African law deals with communal rights and duties and actions. You see that! Law as it is read in the universities; taught in law schools; and practiced by advocates and professionals deal with the individual qua individual but the Igbo African law deals with the individual qua community. You can already see that that it will not be exactly correct for us to measure the Igbo African law, with the yardstick of professional law.

In Igbo Africa, the custodian of law is a human being; mostly the oldest living father of the community who adjudicates with the authority of all the dead fathers, those who have gone before him. His word is a living oracle of law, backed by all the legal echoes of the past. He is the holder of all the rights of the community, the judgment of which he exercises with either the words of his mouth or his staff of authority or Ofo. He has a judgment seat from which only he gives his judgment. His judgment has the backing of Chukwu who alone places elders on that seat and takes them when he wants. At times, the only reason for taking such a judge of the people is that he has judged amiss.

You can now see that the justice which the Igbo African gives is justice according to the truth of Chukwu, because Chukwu is truth. It is not justice according to the law, with which at times, a criminal that has bought a good lawyer or even judge with his stolen money is freed from his crimes. The word of the Igbo African judge is his bond; it is his life; it is his presence. That is why such a word is also his staff. So, it is not even necessary that such a judge keeps an ofo or staff of authority. His word is all the ofo that he needs.

The judicial position for such an Igbo African judge is unique, because he also judges with the authority of the dead. That he judges with the authority of the dead does not mean that he communes with the dead; he never does that. That he judges with the authority of the dead simply means that, as he is the only living person, next to the dead, he maintains the tradition and culture his predecessors have maintained.

To be sure, he is the link between the living and the dead. It was the consideration of the judicial significance of this Igbo African judge that made this proverb: let the elders not die, lest children will mistake the vulture for the fowl”. The elders know what has been, and maintain what is and what will be in accordance with what has been. Yet, it has to be said that the Igbo African judge or elder or lawyer is not only a person, for there is not only one Igbo African community. Each community or town or village or family has her own judge or elder or lawyer; and of course, there is a college of such judges or elders or lawyers for common or general matters. They all know the Igbo African codes of conduct, statutes of life and principles of existence, almost by heart, and direct the Igbo African life and being accordingly.

At this juncture, let me give the theory and practice of Igbo African law and legal occasions.

\section{What Makes a Professional Law?}

If what guides the Igbo African society cannot be called a professional law, then it is logical to explain or in the least, list what makes a law to be called a professional law.

Firstly, the law must be written or documented in hard copy. In these globalized age with the advent of computer and internet, the law of any country that is worth calling a professional law must be on the internet. If that is the case, Britain is a developed country with an unwritten constitution, does it mean their law is not professional or are we being sidelined because Nigeria in general is still a developing country or a third world country? Commenting on this, Okogeri (2006) explained that:

there were institutions exercising judicial power in the respective societies even though the laws were unwritten. The laws administered by these institutions were formulated by the political authorities of the respective communities which were consistent with their system of government. It is therefore not correct that prior to the arrival of the colonial powers, the people in present day Nigeria were without law and order due largely to the absence of writing.

This is also in consonance with views of Obilade (1991:1) who wrote that "Law is a body of customs accepted by members of a community as binding on them"

Customary court in Okafor (1992: p. 94) also sees law as

a rule or body of rules regulating rights and imposing correlative duties, being a rule or body of rules which obtains and is fortified by established usage and which is appropriate and applicable to any particular matter, dispute, issue or question.

To throw more light on the question of being written or not, Ibekwe (1975: p. 297) has this to contribute: "European laws are written, because the art of writing and reading had long become part and parcel of their civilization. Regrettably enough, our own customary law is unwritten. It was handed down the ages from generation to generation. Like a creed, it seems to live in the minds of the people.

Secondly, accessibility is another major characteristic of a professional law. This is more or less a sequel to the above mentioned point of being written. This is in a bid to rule out the plea of ignorance because if one is ignorant of the law of a particular society, how then do you know what they consider as being illegal.

Thirdly, the practitioners must be trained. Normally, this involves studying law in the university; one year in law school 
and acquiring the necessary certificates that will be a proof that he/she is qualified to practice law.

Finally, it is not enough to acquire the necessary certificates and dump. It has to be practicable and is actually being practiced by the legal practitioners. This could mean that it is considered as a profession on its own. If all the medical doctors abandon their certificates for other things, will there be anything like the medical profession? After all said and done, professional law is more or less Western law.

\section{The Metaphysics of Igbo African Law}

Tradition and culture are the legislators of Igbo African law. There has been and will always be a way of doing things, a way thing are done. Such ways determine the codes of conduct, the statues of life and the principles of existence. Such ways guarantee the preservation of life, the maintenance of order and the control of characters.

Since such ways are based on tried traditions and cultures, that have, according to good ordinance of reason and spirit organized the life of the community with the rule of peace and progress, to break or to act against such a way of life is to commit an offence, to commit a crime, against the community, and against the members of the community.

In the light of what has been said, a member of the community becomes dangerous, if by intention and act he or she engages in crimes destructive of the properties or lives of other members of the community. In such occasion, the criminal rule of Igbo African law judges that such an individual or member of the community wants to live at the expense of the community. He wants to be against the community. So, the community must bring him or her to order if the community must live.

From what has just been said, it will easily be discernible, that a criminal is punished, not necessarily because of the crime he has committed, but primarily, because he or she wants to subvert the order or force of the community's way of life. This of course explains why the Igbo African court or council is usually very sensitive, more than the western court, over even "useless" offence or misdeed; so much so, that an offender may not be convicted on the first day he poured oil away, but on the second day he poured the "useless broth" away.

\section{The Igbo African Rule of Law}

The Igbo African rule of law is a rule of social and political control wherein bodies of unwritten codes of conduct, statutes of life and principles of existence naturally born out of the tradition and a culture of organized and lived experience, are known and applied for the management and administration of justice.

From all these, it will be easily discernible that the Igbo African judiciary is a college or council of judges or elders or lawyers where the oldest or at times some other person unanimously elected or appointed is the supreme judge; and the function of such a council or college is not necessarily the invention of laws for all possible offences and all foreseen and unforeseen criminals, but the communalistic and systematic discovery and application of the force of traditional and cultural laws for the control and rule of the life of Igbo African community.

As I have pointed out earlier, Igbo law judges rights and wrongs as they affect the community and not necessarily as they affect the individual. What has just been said is why the western law can never fully understand Igbo African law, not to talk of replacing it in Igbo Africa. Yet, there is another surprise from the Igbo Africans law: the community as understood by Igbo Africans, is an individual, it is a person. This must puzzle the legal-heads of western legal practitioners and even make their hairs to stand and their knees to knock together. But I say it again the Igbo-African community is an individual, it is a person. That is why it has rights that ought to be respected and duties that it must perform. Yet I must tell you again, both for now and forever more, that the Igbo African community is a corporate individual. It is a corporate individual; it is a corporate person; it is a corporate life and being; it is a corporate consciousness.

Because of what has been said about the Igbo community that no one commits a civil or criminal wrong alone, every civil or criminal offence or wrong has a social dimension. That is why, at the end of the Igbo legal judgment day, one or more than one persons are blamed for the offence or wrong he or she committed. Of course, in the Igbo African courts, the offender does not come alone. He or she comes with his or her people whether they are invited or not.

From all that I have tried to clarify, it will be discernible that the enforcement of law is not a significant problem for the Igbo African judiciary. It is not, because the greatest thing that every Igbo African fears is to be ostracized from the community. It will be better for the Igbo person to face death, than to face ex-communication from the community; for outside the community, an individual is nothing. So every individual in Igboland avoids offending the community. However, action groups and masquerade groups actually enforce the rule of Igbo African law, traditionally speaking. Today, there is no reason to suppose that they should not be changed. Just like the codes or statutes or principles of Igbo African law, they were unwritten yesterday, there is also no reason to suppose that they must remain so today or that they should not be written down today.

\section{Differences between Western and Igbo-African Law}

Whenever there are two things on opposing sides, the weakness of one automatically heightens the strength of the other. Having said that, let us look at the most significant differences between so called professional western law and Igbo African traditional law.

1) Western law is studied in the university followed by law school and the necessary certificates. Also the lawyers and custodians of the law are trained in the western legal system. It does not end with training but are practicing as well. This is unlike what is obtainable with Igbo African law.

On the other hand, Igbo African law has no formal network for training of any kind. It does not require any form of training besides the fact that there is no provision for that. Experts in the Igbo African law learn the demands of the Igbo African law in an informal manner by being present in occasions where cases are adjudicated. This explains why, most often, again, the lawyers of the Igbo African law are the council of elders who by virtue of their age and wealth of experience can be said to have acquired a lot of training by virtue of their having been present in past occasions where judicial decisions were taken.

2) Western law is basically universal while the traditional law is culture-specific. Western law is universal because it is the same law that applies to every town or city as the case may be. With Igbo traditional law, there are as many laws as there 
are communities and towns. One can now understand why it has been said that traditional law is not uniform in substance and in form. Aniagolu (1975: p. 105) stated that

customary law is not constant but relative and varies sometimes within special localities; in land with the place where the land is situated; in other civil causes with the personal law of the parties and in other circumstances with the area of the jurisdiction of the court.

What he is trying to point out is that customary law and custom varies from society to society. Society to society is even far reached; what is obtainable in a village is different from what is the situation in the next village.

3) Western law is individualistic while traditional law is communalistic. Before people started feeling the influence of European culture and the influence being exerted by Christianity and its ethics, the people lived communally and I believe that they still do to some extent. Oputa (1975: p. 7) explains that

"the individual was a member not only of his immediate family but also of his extended family, and even village, and this group membership was very real. He dares not break any laws or face ostracism”.

He went on to explain that the society at that time and now provided few opportunities for "individualism" in behaviour. In other words, what affects one affects all. Also commenting on this is Ibekwe (1975: p. 297) who maintained that the European way of life is fundamentally individualistic, while our own way of life is particularly communal. There is communality of landed properties, wives etc. It is more like "I am because we are and since we are, therefore I am”.

4) Traditional law is more superior to the western law. How do I mean? Western law is made by a few people for all the people. This is unlike what is obtainable in the traditional society where everyone has a say before the final deliberation and subsequent adoption into law. This is exemplified in the term coined by Okafor called "ohacracy" where whatever is adopted as law passes through the people. This might look contradictory considering that the agencies in the Igbo society do make laws. I wish to point out that the laws made by the Umunna for instance is primarily meant to guide the members of a particular kindred and cannot be binding on other kindreds. The essence of the laws by the agencies is to guide and direct their members because "ana ama mma esi na ulo" which means that being good starts from the home or inside. However, I wish to reiterate that the laws meant for the whole community must be vetoed by the people.

5) Furthermore, western law is written in texts and documented. Well Igbo law is written but on the tablets of the human heart. By writing on the tablets of the human heart, it is more or less based on moral or conscience. Everyone in the community including its lawyers have it in bold prints. Worthy of note is that in most extreme case, the lawyers in the traditional setting includes the Dibias who by virtue of the authority attached to his ofo and his relationship with the spirit world, can also participate in adjudicating cases.

6) The western or professional law as the case may be is based on rationalism, while the Igbo African law is based on the force of the conscience; that is why it is said that it is written on the tablets of the human heart. Sequel to the above point, in the case of a default or committing a legal error; by implica- tion, the conscience first condemns before the society condemns. The Igbos even has a saying to that effect that "conscience is the best judge". Here, the conscience judges you before either respectively or collectively the traditional legal custodians will deliberate and label the offence so as to determine a corresponding punishment or penalty.

Despite their differences, both western and Igbo traditional laws strive to maintain peace and order in the society; protect lives and properties.

\section{Relevance or Strong Points of Igbo Traditional Law}

1) Speedy hearing free of endless adjournments and unending trials. After all, it has been said that justice delayed is justice denied. There are no closed sessions so that what you see is what you get. Writing on this, Oraegbunam explains that the most striking feature of the customary adjudicatory system is the speedy dispensation of justice. Hearing was done openly with all the parties and the witnesses hearing each other unlike the Western system of ordering witnesses out of court and out of hearing. Hearsay evidence was allowed. Proceedings were conducted and Judgment given instantly unlike the Western system which is fraught with the possibilities of endless adjournments and delays

2) Secondly, trial in the Igbo traditional society is economical. There is economy of money, time and mental stress associated with endless proceedings.

3) Family law: Under family law in the Igbo society, we have marriage rites, dissolution of marriages, introduction of families, bride price, guardianship etc. All these and many more are regulated under the native law and custom. The advent of Christianity and civilization has not been able to change it. Even if one gets married in faraway London, the marriage is not considered complete until the traditional rites are completed. There are no ways around it.

4) Land law: With the recent fuss over land ownership vis-àvis the western law. Who had or ever possessed certificate of ownership in the Igbo society? For them their word is their bond. Again, people were not as greedy as they are now, so there was no room for documentation for land ownership. Onwuamaegbu (1975: p. 361) stated that the federal government "observed that the making and giving of receipts are unknown to native land law, and the giving of such is not within the nile of native law and custom".

5) Succession: In the absence of a written will, how do they Igbos succeed the dead? How do the children of a man succeed him after death? Till today, the Igbo society has their laws of succession that are still applicable. For instance, if a mother dies, it is her daughters even if they are married that will share her things and not her daughter in laws. Depending on the relationship that exists between the daughter and the daughters in law, the former may decide to give them a share of the booty though it is not binding on them.

\section{Conclusion}

Igbo African law is the body of unwritten codes of conduct, statutes of life and principles to which Igbo African people ought to conform their lives, and which the college or council of elders or judges or lawyers as the case may be, adjudicate and some action-groups enforce.

Igbo African law is meant for the systematic control of the 
whole life of individuals, but only as members of the community. The promotion of the common good is one of the most important criteria for assessing the efficiency and goodness of any law and through it; people in the society are able to achieve their private individual goods. After all, as can be seen from the words of Ibekwe (1975: p. 297) that "European laws are written, because the art of writing and reading had long become part and parcel of their civilization. Regrettably enough, our own customary law is unwritten. It was handed down the ages from generation to generation. Like a creed, it seems to live in the minds of the people".

From time immemorial, our native laws have been and are still there for us. Does the fact that our law does not conform to that of the Westerners make it less a law? If we discard our identity to look like the westerners, who will look like us? No wonder the Igbo saying that "aham efuna" which translates to read "let my name not be lost". The Igbo native laws just like every other law is always open to amendments considering the fact that law is meant for man and not man for law. That notwithstanding, the ultimate aim is an ordered society. That means that it does not matter the origin or the people that has the law as long as it brings peace, order and harmony to the society.

\section{REFERENCES}

Abayomi, S. (2002). Advertising Practices in Nigeria: Legal Provisions,
Sanctions and Professional Regulations. In S. Okunna (Ed.), Teaching Mass Communication. Enugu: New Generation Books.

Ajibola, P. (1991). Towards a restatement of Nigeria Customary Laws. Lagos: Federal Ministry of Justice Law Review Series.

Aniagolu, A. (1975). Aspects of customary marriage and divorce and their incidents upon family life. In Elias et al. (Eds.), African Indigenous Laws. Enugu: Government Printer.

Begho, M. (1975). The Mechanics of Customary Law. In Elias et al. (Eds.), African Indigenous Laws. Enugu: Government Printer.

Ibekwe, D. (1975). Conflicts of Cultures and our Customary Laws. In Elias et al. (Eds.), African Indigenous Laws. Enugu: Government Printer.

Obiwulu, A. (2007). The Role of Law in Nigerian Democracy. Journal of Nigeria Democracy and Global Democracy at 2007 World Philosophy Day. Awka: Nnamdi Azikiwe University.

Okafor, F. U. (1992). Igbo Philosophy of Law. Enugu: Fourth Dimension Publishing Co. Ltd.

Okogeri (2006). Eziokwu bu Ndu in Igbo Contemporary Law. Studies in Philosophy, 1, 172-179

Onwuamaegbu, O. (1975). Nigerian Indigenous Land Law. In Elias et al. (Eds.), African Indigenous Laws. Enugu: Government Printer.

Oputa, C. (1975). Crime and the Nigerian society. In Elias et al. (Eds.), African Indigenous Laws. Enugu: Government Printer.

Oraegbunam, I. (2010). The Principles and Practice of Justice in Traditional Igbo Jurisprudence. 53-85. 